\title{
Inhibitory effects of Mezoneuron benthamianum root extracts on oral cariogenic microorganisms and 2,2- diphenyl-1-picrylhydrazyl (DPPH) scavenging radical
}

Paul M. Osamudiamen ${ }^{1,2^{*}}$ (D), Bolaji B. Oluremi ${ }^{3}$, Fisayo T. Osamudiamen ${ }^{4}$ and Olapeju O. Aiyelaagbe ${ }^{2}$

\begin{abstract}
Background: Chewing sticks are commonly used as oral hygiene tool in Africa and reactive oxygen species have been linked to the cause of degenerative diseases because of their ability to induce oxidative damage to biological molecules. Plants have been a long source of dietary antioxidants as most plants have been found to exhibit excellent antioxidant potentials. Mezoneuron benthamianum is a plant that is used locally as chewing sticks in southwest, Nigeria, but its use as a therapeutic agent in dental caries, a disease caused by bacteria especially Streptococcus mutans is poorly investigated. This study was therefore designed to investigate the anticaries activities of the crude extracts of $M$. benthamianum root against four clinical oral pathogens (Staphylococccus aureus, Escherichia coli, Pseudomonas aeruginosa and Streptococcus mutans) and the antioxidant activities using 2,2-diphenyl-1-picrylhydrazyl (DPPH).

Results: The results of this study showed that $M$. benthamianum had a consistent activity against all the bacterial organisms tested, with the ethyl acetate extract having the highest anticaries activity with minimum inhibitory concentration values of 78 and $156 \mu \mathrm{g} / \mathrm{mL}$, while the hexane extract had the least anticaries activity with MIC values of $2500 \mu \mathrm{g} / \mathrm{ml}$ against $S$. mutans and $E$. coli respectively. The results also revealed that the ethyl acetate and aqueous methanol extract exhibited a higher antioxidant activity $\left(\mathrm{IC}_{50}=23.70\right.$ and $\left.21.30 \mathrm{\mu g} / \mathrm{mL}\right)$ than standard ascorbic acid $\left(\mathrm{IC}_{50}=38.20 \mu \mathrm{g} / \mathrm{mL}\right)$.
\end{abstract}

Conclusion: This study demonstrated the anticaries and antioxidant potentials of M.benthamianum and therefore justifies the folkloric use of $M$. benthamianum in oral hygiene.

Keywords: Dental caries, Mezoneuron benthamianum, Chewing sticks, Streptococcus mutans

\footnotetext{
* Correspondence: pmosamudiamen@gmail.com;

pmosamudiamen@bellsuniversity.edu.ng

'Department of Chemical Sciences, Bells University of Technology, Ota, Ogun

State, Nigeria

${ }^{2}$ Department of Chemistry, University of Ibadan, Ibadan, Nigeria

Full list of author information is available at the end of the article
}

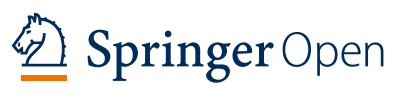

(- The Author(s). 2020 Open Access This article is licensed under a Creative Commons Attribution 4.0 International License which permits use, sharing, adaptation, distribution and reproduction in any medium or format, as long as you give appropriate credit to the original author(s) and the source, provide a link to the Creative Commons licence, and indicate if changes were made. The images or other third party material in this article are included in the article's Creative Commons licence, unless indicated otherwise in a credit line to the material. If material is not included in the article's Creative Commons licence and your intended use is not permitted by statutory regulation or exceeds the permitted use, you will need to obtain permission directly from the copyright holder. To view a copy of this licence, visit http://creativecommons.org/licenses/by/4.0/. 


\section{Background}

Dental caries is a condition affecting half of the entire human population [1] and it is caused by bacteria found in the mouth especially Streptococcus mutans. It is a bacterial initiated demineralization of the hard tissue structures of the tooth [2]. Natural products have been used from the past for their antibacterial effect, but recently there have been investigations about promising agents for the prevention of oral diseases such as dental caries [3]. In addition, research has shown the potential of natural products in remineralising tooth surfaces affected by dental caries [4]. Hence, medicinal plant based extracts and their derivatives have been explored for the anti-cariogenic and anticancer effects $[5,6]$. Furthermore, the biological system undergoes metabolic processes involving redox reactions which generate reactive oxygen species (ROS). Reactive oxygen species have been linked to the causes of degenerative diseases such as cardiovascular disease, cancer, diabetes, hypertension and neurodegenerative disorders because of their ability to induce oxidative damage to biological molecules [7]. Normally, the ROS generated during metabolic process are detoxified by the antioxidant enzymes eg glutathione reductase by producing antioxidant compounds like glutathione and creatine, in order to achieve equilibrium between the ROS generation and its detoxification within the system. But when the generation of ROS overtakes the antioxidant defence of the cell, a phenomenon that leads to potential damage occurs, [8]. Plants have long been source of dietary antioxidants. It is believed that two-thirds of the world's plant species have medicinal importance, and almost all of these have excellent antioxidant potential [9]. In Africa, the use of chewing sticks is the most common means of maintaining oral hygiene and preventing dental caries and Mezoneuron benthamianum is plant that is used locally as a chewing stick in southwestern Nigeria [10] and It has been traditionally used in the management of several diseases including dysentery, urethral discharges, skin diseases and wounds [11]. However, its use as a therapeutic agent in preventing dental caries has not been extensively investigated. This study was therefore designed to investigate its antimicrobial activities against four oral clinical pathogens (Staphylococccus aureus, Escherichia coli, Pseudomonas aeruginosa and Streptococcus mutans) and antioxidant activities using 2,2diphenyl-1-picrylhydrazyl (DPPH).

\section{Methods}

\section{Plant preparation}

The plant samples of $M$. benthamianum Baill. were obtained in Ibadan and authenticated at the Department of Botany, University of Ibadan, Nigeria, where voucher specimen is being deposited in the herbarium. (No: UIH-22401).

\section{Plant extraction}

The dried, ground root of $M$. benthamianum $(2.74 \mathrm{~kg})$ was extracted by maceration with methanol $(10 \mathrm{~L} \times 2$, for $72 \mathrm{~h}$ each) and the extracts were concentrated using rotary evaporator under reduced pressure to give dark brownish extract $(200 \mathrm{~g})$. This was then dissolved in aqueous methanol and was further partitioned with the aid of a separating funnel into hexane, ethyl acetate and aqueous methanol fractions to yield $5 \mathrm{~g}, 70 \mathrm{~g}$ and $100 \mathrm{~g}$ respectively.

\section{Antimicrobial assay Microbial strains}

The bacterial test strains used in this study were Staphylococcus aureus, Pseudomonas aeruginosa, Escherichia coli and Streptococcus mutans isolated from carious teeth of patients at the dental clinic of the University College Hospital, University of Ibadan, Ibadan, Oyo State. In addition, three typed strains obtained from the American Type Culture Collection (ATCC) were also used namely: Staphylococcus aureus (ATCC 29213), Pseudomonas aeruginosa (ATCC 27855), E. coli (ATCC 35218) and the bacterial strains were maintained on agar slant at $4{ }^{\circ} \mathrm{C}$ prior to being used.

\section{Culture media}

Nutrient Agar (NA) was used for determining the Minimum Inhibitory Concentration (MIC) while Mueller Hinton Agar (MHA) was used for the determination of the Minimum Bactericidal Concentration (MBC).

\section{Inoculation preparation}

At least four well isolated colonies of the same type from a culture agar plate were selected and touched the top of colony with a loop and transferred to a tube containing $4 \mathrm{ml}$ of a suitable broth such as tryptic soy broth (TSB). The suspension was incubated at $37^{\circ} \mathrm{C}$ and the size was adjusted to the $0.5 \mathrm{McFarland}$ standard turbidity [12], approximately $1.5 \times 10^{6} \mathrm{CFU} / \mathrm{ml}$.

\section{Preparation of antimicrobial plates}

The diluted methanol extracts were added to the melted and cooled medium in a ratio of 1 part extract sample agent to 9 parts medium ( $2 \mathrm{ml}$ of plant extract to $18 \mathrm{ml}$ of Mueller Hinton agar for each Petri dishes plate) with most susceptibility test. Gentamycin $(0.62-5 \mu \mathrm{g} / \mathrm{ml})$ was used as control for the microorganisms assay.

\section{Inoculation of test organisms}

Full each well of multiple-inoculator with inoculums test organisms and dip the tip of multiple-inoculator on Mueller Hinton Agar plates and incubate at $37^{\circ} \mathrm{C}$ for $24 \mathrm{~h}$.

The antibacterial activity of the extracts was determined using the agar well diffusion technique with slight 
modification [13, 14] and Gentamycin (Sigma) was used as a positive control. Nutrient agar plates were seeded with $100 \mu \mathrm{L}$ of an overnight culture of each bacterial strain (equivalent to $10^{7}-10^{8} \mathrm{CFU} / \mathrm{ml}$ ). The seeded plates were allowed to set and a standard cork borer of $8.00 \mathrm{~mm}$ diameter was used to cut uniform wells on the surface of the agar. Each plant extract was prepared into a concentration of $200 \mathrm{mg} / \mathrm{mL}$ from the dried extract by dissolving $2 \mathrm{~g}$ of the individual plant extract in $10 \mathrm{ml}$ of methanol, then $2 \mathrm{ml}$ of the mixture was diluted serially four times with $2 \mathrm{ml}$ of the methanol to give $100 \mathrm{mg} / \mathrm{ml}$, $50 \mathrm{mg} / \mathrm{ml}, 25 \mathrm{mg} / \mathrm{ml}, 12.5 \mathrm{mg} / \mathrm{ml}$ and $6.25 \mathrm{mg} / \mathrm{ml}$. The wells of the agar medium were then filled with $100 \mu \mathrm{L}$ of each extract at the different concentrations of $6.25,12.5$, 25, 50 and $100 \mathrm{mg} / \mathrm{ml}$ using calibrated Pasteur pipette. Gentamicin at $10 \mu \mathrm{g} / \mathrm{ml}$ was used as the positive control while methanol as the negative control. The plates were left for $45 \mathrm{~min}$ to allow the diffusion of the extracts and controls through the agar medium after which they were incubated at $37^{\circ} \mathrm{C}$ for $24 \mathrm{~h}$. Each test was carried out in duplicates. Zones of growth inhibition of the various concentrations of the extracts and the controls were measured. The mean zone of inhibition less than $8 \mathrm{~mm}$ is considered as no activity.

\section{Determination of minimum inhibitory concentration and minimum bactericidal concentration}

Minimum inhibitory concentration (MIC) was determined using the agar dilution method of [15] with slight modifications. The extract of $20 \mathrm{mg} / \mathrm{ml}$ was serially diluted in test tubes to give a final concentration in the range of $10,5.0,2.5,1.25,0.625,0.3125,0.156,0.078 \mathrm{mg} /$ $\mathrm{mL}$. Two millilitre of each dilution of the extract was mixed with $18 \mathrm{ml}$ of Mueller Hinton agar, poured into $10 \mathrm{~cm}$ diameter Petri dishes and allowed to set. After allowing the agar to dry for about $30 \mathrm{~min}$, each plate was inoculated with 1:100 dilution of overnight broth cultures of each test organisms containing $1.0 \times 108 \mathrm{CFU} /$ $\mathrm{ml}$ (according to 0.5 McFarland standard) and incubated for $24 \mathrm{~h}$ at $37^{\circ} \mathrm{C}$. Nutrient agar plates with extract but without an organism and one containing only organism served as positive and negative control respectively. Each test was carried out in duplicate. The plates were then examined for the presence of growth after the incubation period. The least concentration that gave no visible colonies of the test organism was taken as the minimum inhibitory concentration of the extract.

The miminum bactericidal concentration (MBC) of the extracts was determined by taking samples from plates with no visible growth in the MIC assay and subcultured on to freshly prepared nutrient broth and later incubated at $37^{\circ} \mathrm{C}$ for $48 \mathrm{~h}$. The $\mathrm{MBC}$ was taken as the lowest concentration of the extract that did not allow any bacterial growth on the surface of the agar plates or technically as the lowest concentration of extract which produced $99.9 \%$ killing of the inoculums.

\section{DPPH antioxidant assay}

The free radical scavenging activity of the compounds was measured by the 2,2-diphenyl-1\-picrylhydrazyl (DPPH) method described by, Brand-Williams et al., (1995) with slight modifications. Briefly, a $0.1 \mathrm{mM}$ solution of DPPH in methanol was prepared and $1.0 \mathrm{ml}$ of this solution was added to $0.5 \mathrm{ml}$ of the samples dissolved in methanol and using a range of $12.5-200 \mu \mathrm{g} / \mathrm{ml}$. After $20 \mathrm{~min}$, the absorbance was measured at $517 \mathrm{~nm}$. The DPPH radical scavenging activity was calculated according to the following equation:

$$
\begin{aligned}
& \text { DPPH scavenging activity }(\%) \\
& \quad=\left[\left(A_{o}-A_{I}\right) / A_{o}\right] \times 100
\end{aligned}
$$

Where $A_{o}$ is the absorbance of the control and $A_{\mathrm{I}}$ is the absorbance in the presence of the test substance. DPPH solution alone served as control $\left(\mathrm{A}_{\mathrm{o}}\right)$. A graph of $\%$

\begin{tabular}{|c|c|c|c|c|c|c|c|c|c|c|c|c|c|c|c|c|c|c|c|c|c|}
\hline \multirow[t]{4}{*}{ Test Organisms } & \multicolumn{20}{|c|}{ M. benthaminaum Extracts } & \multirow{4}{*}{$\begin{array}{l}\text { Positive control } \\
\text { Gentamicin } \\
\mu \mathrm{g} / \mathrm{mL} \\
10\end{array}$} \\
\hline & $\overline{\mathrm{MBM}}$ & & & & & $\mathrm{MBH}$ & & & & & MBE & & & & & MBA & & & & & \\
\hline & \multicolumn{20}{|c|}{ Concentrations $(\mathrm{mg} / \mathrm{mL}) /$ Zone of Inhibition $(\mathrm{mm})$} & \\
\hline & 6.25 & 12.5 & 23 & 50 & 100 & 6.25 & 12.5 & 25 & 50 & 100 & 6.25 & 12.5 & 25 & 50 & 100 & 6.25 & 12.5 & 25 & 50 & 100 & \\
\hline P. aeruginosa (ATCC 27855) & 12 & 14 & 16 & 18 & 24 & 8 & 8 & 14 & 16 & 18 & 18 & 8 & 14 & 16 & 22 & 12 & 12 & 14 & 16 & 18 & 18 \\
\hline P. aeruginosa $(\mathrm{LIO})$ & 12 & 14 & 16 & 18 & 24 & 10 & 12 & 14 & 16 & 18 & 16 & 14 & 20 & 22 & 24 & 8 & 8 & 16 & 18 & 20 & 16 \\
\hline S. aureus (ATCC 29213 & 14 & 16 & 18 & 22 & 26 & 8 & 8 & 8 & 8 & 10 & 24 & 8 & 20 & 24 & 26 & 10 & 14 & 16 & 18 & 20 & 24 \\
\hline S. areus $(\mathrm{LIO})$ & 12 & 14 & 16 & 18 & 22 & 8 & 8 & 8 & 8 & 10 & 22 & 12 & 20 & 22 & 24 & 8 & 12 & 14 & 16 & 18 & 22 \\
\hline E. coli (ATCC 35218) & 8 & 12 & 14 & 16 & 22 & 8 & 8 & 8 & 8 & 8 & 20 & 8 & 12 & 14 & 16 & 8 & 12 & 14 & 16 & 18 & 20 \\
\hline E. coli $(\mathrm{LIO})$ & 12 & 14 & 16 & 18 & 22 & 8 & 8 & 8 & 8 & 10 & 20 & 8 & 18 & 22 & 24 & 16 & 18 & 24 & 26 & 28 & 20 \\
\hline S. mutans $(\mathrm{LIO})$ & 12 & 14 & 17 & 19 & 23 & 10 & 10 & 11 & 12 & 14 & 12 & 14 & 17 & 20 & 23 & 11 & 13 & 14 & 16 & 19 & 22 \\
\hline
\end{tabular}

Table 1 Antimicrobial activities of $\boldsymbol{M}$. benthaminaum extracts

KEY: MBM M. benthamianum methanol crude extract, $M B H M$. benthamianum hexane extract, $M B E M$. benthamianum ethyl acetate extract, $M B A M$ M. benthamianum aqueous methanol extract, LIO Locally isolated organism " $8 \mathrm{~mm} "=$ No inhibition 
Table 2 Minimum Inhibitory Concentration (MIC) and Minimum Bactericidal Concentration (MBC) of M. benthamianum Extracts

\begin{tabular}{|c|c|c|c|c|c|c|c|c|}
\hline \multirow[t]{3}{*}{ Test Organisms } & \multicolumn{8}{|c|}{ M. benthamianum Extracts } \\
\hline & MBM & $\mathrm{MBH}$ & MBE & MBAM & MBM & $\mathrm{MBH}$ & MBE & MBAM \\
\hline & \multicolumn{4}{|c|}{$\mathrm{MIC}(\mu \mathrm{g} / \mathrm{mL})$} & \multicolumn{4}{|c|}{$\mathrm{MBC}(\mu \mathrm{g} / \mathrm{mL})$} \\
\hline $\begin{array}{l}\text { P. aeruginosa } \\
\text { (ATCC 27855) }\end{array}$ & 313 & 10,000 & 625 & 625 & $>625$ & $>20,000$ & $>625$ & $>625$ \\
\hline P. aeruginosa $(\mathrm{LIO})$ & 313 & 10,000 & 625 & 625 & $>625$ & 20,000 & $>625$ & $>625$ \\
\hline $\begin{array}{l}\text { S. aureus } \\
\text { (ATCC 29213) }\end{array}$ & 1250 & 2500 & 625 & 625 & $>625$ & $>20,000$ & $>625$ & $>625$ \\
\hline S. areus $(\mathrm{LIO})$ & 1.25 & 2500 & 625 & 78 & $>625$ & 2500 & 625 & $>625$ \\
\hline $\begin{array}{l}\text { E. coli } \\
\text { (ATCC 35218) }\end{array}$ & 78 & 2500 & 78 & 78 & $>625$ & 20,000 & 156 & $>625$ \\
\hline E. coli $(\mathrm{LIO})$ & 78 & 2500 & 78 & 78 & 78 & $>20,000$ & 625 & 78 \\
\hline S. mutans (LIO) & 125 & 2500 & 163 & 78 & $>625$ & 15,000 & 468 & $>625$ \\
\hline
\end{tabular}

Key: MBM M. benthamianum methanol crude extract

$M B H$ M. benthamianum hexane extract

MBE M. benthamianum ethyl acetate extract

MBAM M. benthamianum aqueous methanol extract

LIO Locally isolated organism

inhibition against concentration was plotted and $\mathrm{IC}_{50}$ determined using the GraphPad Prism 7.0 programme.

\section{Results}

The results of the antimicrobial activities of Mezoneuron benthamianum extracts (Tables 1 and 2; Fig. 1) showed that the crude methanol extract (MBM), the ethyl acetate (MBE) as well as the aqueous methanol extract (MBAM) had the highest antimicrobial activities against the seven strains of microorganisms used with activity indices (ratio of the zone of inhibition of the extracts to the zone of inhibition of the gentamicin - the positive control) in the range of 3.2-5.25, 3.1-6.0 and 2.7-5.6 respectively. While the hexane extract had the least antimicrobial activity with activity index in the range of 0.0-4.38. This result shows that the polar extract exhibited more antimicrobial activity against the microorganisms as confirmed from the Minimum Inhibitory Concentration (MIC) and Minimum Bactericidal Concentration (MBC) values (Table 2). The polar extracts of $M$. benthamianum are rich in polyphenols, which have been established to have antimicrobial and anticariogenic properties $[5,16]$.

In addition, the results of the antioxidant activities of the crude extracts (Figs. 2 and 3) show that MBM, MBE and MBAM exhibited strong antioxidant activity as shown by their percentage scavenging activities as well as their $\mathrm{IC}_{50}$ of $63.79,23.7$ and $21.3 \mu \mathrm{g} / \mathrm{mL}$, while the

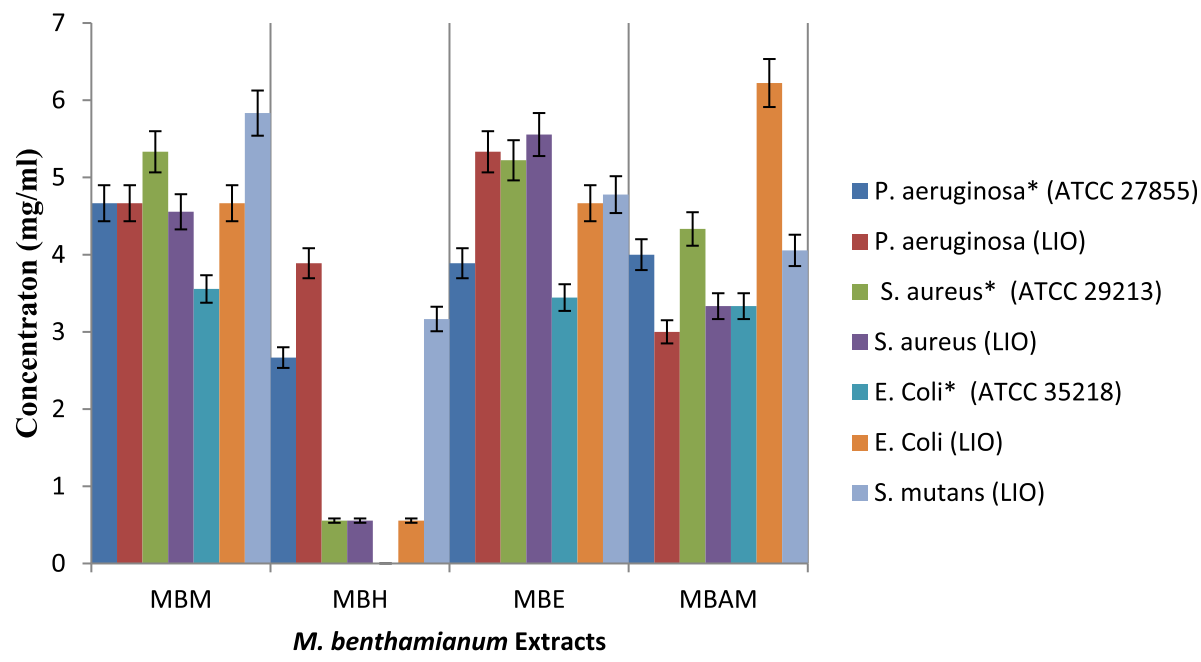

Fig. 1 Antimicrobial Activity indices of Crude extracts. Key: $M B M=M$. benthamianum methanol crude extract, $M B H=M$. benthamianum hexane extract, $\mathrm{MBE}=\mathrm{M}$. benthamianum ethyl acetate extract, $\mathrm{MBAM}=\mathrm{M}$. benthamianum aqueous methanol extract, $\mathrm{LIO}=\mathrm{Locally}$ isolated organism. All experimental values are denoted as mean \pm SEM 


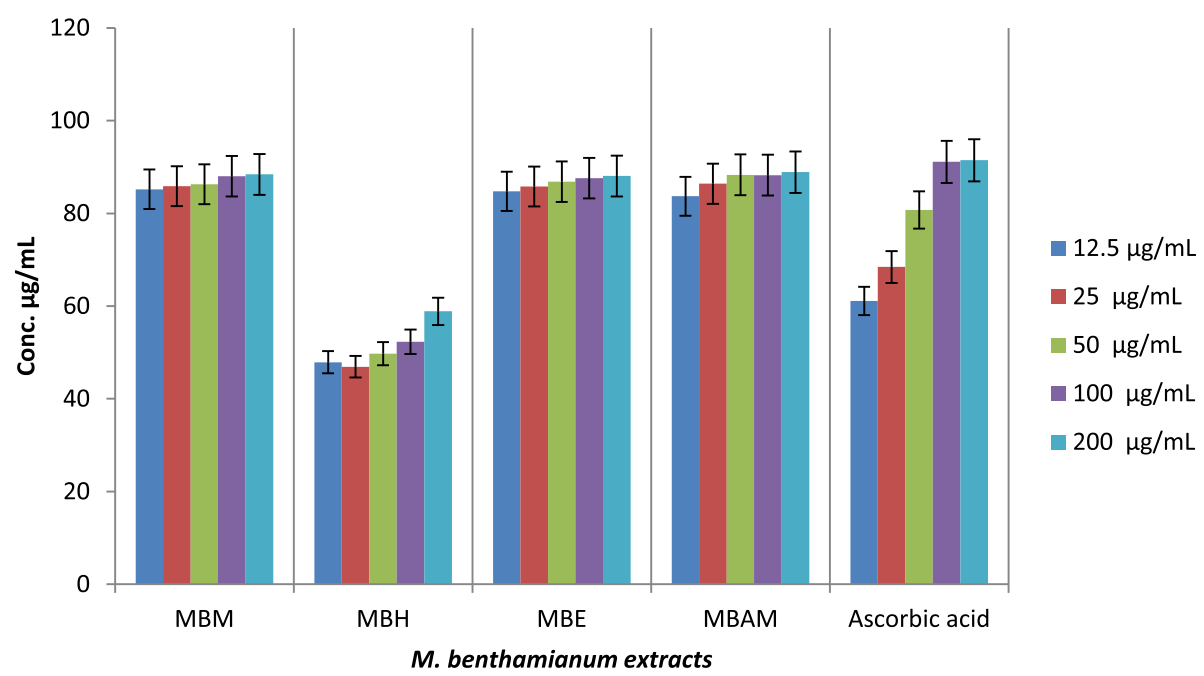

Fig. $2 \%$ Scavenging activity of M.benthamianum extracts. Key: $M B M=M$. benthamianum methanol crude extract, $M B H=M$. benthamianum hexane extract. $\mathrm{MBE}=M$. benthamianum ethyl acetate extract, $\mathrm{MBAM}=M$. benthamianum aqueous methanol extract. All experimental values are denoted as mean \pm SEM

hexane extract $(\mathrm{MBH})$ had low antioxidant activity with $\mathrm{IC}_{50}$ of $265 \mu \mathrm{g} / \mathrm{mL}$. MBE and MBM had a greater antioxidant activity than the standard drug ascorbic acid $\left(\mathrm{IC}_{50}=38.20\right)$, which shows that polar extracts of $M$. benthamianum could be a source of good antioxidant compounds.

\section{Discussion}

Dental caries is the most prevalent disease affection the oral cavity. It cuts across different segment of the society. Although different microorganisms are implicated in dental caries, Streptococcus mutans is considered as the primary aetiological agent. Natural products are used routinely for oral hygiene and treatment of dental caries [3]. In Africa, especially Nigeria chewing sticks are commonly used in maintaining oral hygiene and preventing dental caries. While this is the first report of the antimicrobial activities of extracts of $M$. benthaminaum against cariogenic organisms, the antimicrobial potential of $M$. benthamianum can be attested to in previous reports. The report of [17], which reported the antimicrobial activities of the petroleum ether, chloroform and ethyl

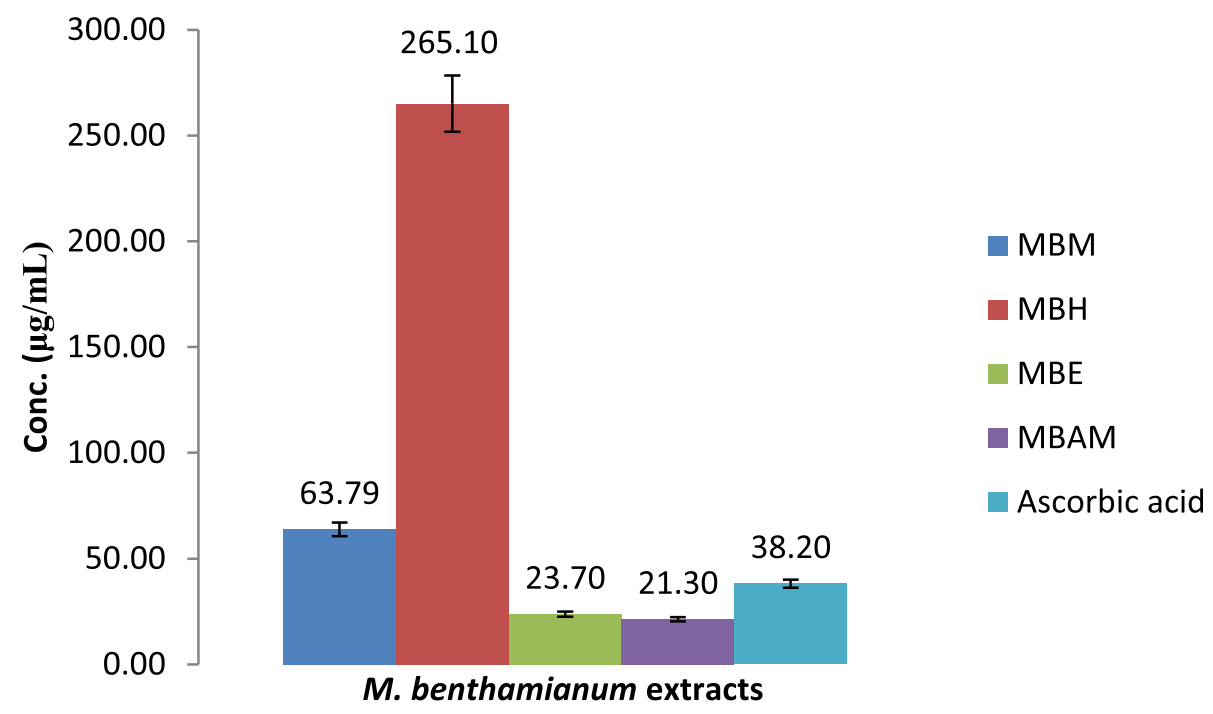

Fig. 3 Antioxidant Activity $\left(\mathrm{IC}_{50}\right) \mathrm{M}$. benthamianum extracts. Key: $\mathrm{MBM}=\mathrm{M}$. benthamianum methanol Crude extract, $\mathrm{MBH}=\mathrm{M}$. benthamianum hexane extract, $\mathrm{MBE}=M$. benthamianum ethyl acetate extract, $\mathrm{MBAM}=\mathrm{M}$. benthamianum aqueous methanol extract, All experimental values are denoted as mean \pm SEM 
acetate extracts of $M$. benthamianum against $S$. aureus, $E$. coli and $P$. aeruginosa with MIC values ranging from 125 to $1000 \mu \mathrm{g} / \mathrm{mL}$, correlates with this study as it is observed that the MBM, MBE and MBAM had the highest activities with MIC values ranging from 78 to $625 \mu \mathrm{g} / \mathrm{mL}$, and they also inhibited S.mutans with MIC of 125, 163 and $78 \mu \mathrm{g} / \mathrm{mL}$, respectively. The observed activities of MBM, MBE and MBAM could be due to the presence of polyphenolic compounds such as resveratrol and piceatannol which have previously been reported form the ethyl acetate extracts [16]. The potential of $M$. benthamianus as a strong antioxidant agent could be attested to by previous reports. Fayemi et al, 2012 [18], reported the DPPH antioxidant activity of the ethanolic extract of M.benthamianum with $\mathrm{IC}_{50}$ of $781.5 \mu \mathrm{g} / \mathrm{mL}$, while [17] reported the DPPH antioxidant activity of the petroleum ether and chloroform extracts of $M$. benthamianum with $\mathrm{IC}_{50}$ of 15.33 and $19.72 \mu \mathrm{g} / \mathrm{mL}$. These values are comparable to those obtained in our study as MBE and MBAM had the highest antioxidant activities with $\mathrm{IC}_{50}$ of 23.70 and $21.30 \mu \mathrm{g} / \mathrm{mL}$, even higher than that of standard ascorbic acid $(38.20 \mu \mathrm{g} / \mathrm{mL})$. The strong antioxidant activity of these extracts could be attributed to the presence polyphenols some of which have been reported [16].

\section{Conclusion}

In this study, the anticaries assay of the extracts of $M$. benthamianum revealed that the extracts possess inhibitory properties against the clinical isolates of the different cariogenic microorganisms including S. mutans. They also demonstrated a strong antioxidant activity against DPPH scavenging radical. This is the first report of the anticaries activities of Mezoneuron benthamianum extracts and its further corroborate the folkloric use of this plant in maintaining dental hygiene and preventing dental caries.

\footnotetext{
Abbreviations

DPPH: 2,2-diphenyl-1-picrylhydrazyl; IC 50 : 50\% Inhibitory concentration i.e. the concentration of extract that can achieve $50 \%$ of intended activity; ROS : Reacted Oxygen species; ATCC: American Type culture collection; LIO: Locally isolated organism; NA: Nutrient agar; MBA: Mueller Hinton Agar; MIC: Minimum Inhibitory concentraion; MBC: Minimum bactericidal concentration; TSB: Triptic soy broth; CFU: Colony forming unit; NCCL S: National Committee for Clinical Laboratory; MBM: Mezoneuron benthamianum Methanol crude extract; MBAM : Mezoneuron benthamianum aqueous methanol extract; MBE: Mezoneuron benthamianum Ethyl acetate extract; MBH: Mezoneruon benthamianum hexane extract
}

\section{Acknowledgments}

The authors thank the Head of Department, Pharmaceutical Microbiology, University of Ibadan for granting the bench space where part of this work was carried out. The selfless service of Mr. Sunday Makinde is also highly appreciated.

\section{Authors' contributions}

PMO has designed the experiment, performed the literature search, data acquisition, statistical analysis, and manuscript preparation and editing. BBO was involved in the some experimental studies and also reviewed the manuscript. FTO was involved in the data acquisition and also reviewed the manuscript. OOA was involved in the experimental concept and design and also reviewed the manuscript. All the authors have read and approve of the manuscript.

\section{Funding}

This research did not receive any specific grant from funding agencies in the public, commercial, or not-for-profit sectors.

\section{Availability of data and materials}

All the data generated or analysed during this study are included in this published article.

Ethics approval and consent to participate

Not applicable.

\section{Consent for publication}

The authors approved the manuscript for this publication.

\section{Competing interests}

The authors declare that they have no competing interest.

\section{Author details}

${ }^{1}$ Department of Chemical Sciences, Bells University of Technology, Ota, Ogun State, Nigeria. ${ }^{2}$ Department of Chemistry, University of Ibadan, Ibadan, Nigeria. ${ }^{3}$ Department of Pharmaceutical Microbiology, University of Ibadan, Ibadan, Nigeria. ${ }^{4}$ Department of Veterinary Microbiology, University of Ibadan, Ibadan, Nigeria.

Received: 1 February 2020 Accepted: 3 July 2020

Published online: 20 July 2020

\section{References}

1. World Health Organisation. Retrieved from Sugars: Dental Caries-Key facts. 2019. http://www.who.int/oral_health/publications/sugars-dental-carieskeyfacts/en.

2. Ozden F, Ozgonenel O, Ozden B, Aydogdu A. Diagnosis of periodontal diseases using different classification algorithms: a preliminary study. Niger J Clin Pract. 2015;18:416-21.

3. Borhan-mojabi K, Azimi S. Antimicrobial Natural Products in Oral Health. In Mendez Vilas, Microbial pathogens and strategies for combating them. Sci Technol Educ. 2013;2:932-9.

4. He L, Deng D, Zhou X. Novel tea polyphenol-modified calcium phosphate nanoparticle and its remineralization potential. J Biomed Material Res Part B: Appl Biomaterials. 2015;103(8):1525-31.

5. Ferrazzano GF, Amato I, Ingenito A, Zarrelli A, Pinto G, Pollio A. Plant polyphenols and their anti-cariogenic properties: a review. Molecules. 2011; 16(2):1486-507.

6. Hambire C, Jawade R, Patil A, Wani VR, Kulkarni A, Nehete PB. Comparing the antiplaque efficacy of $0.5 \%$ Camellia sinensis extract, $0.05 \%$ sodium fluoride, and $0.2 \%$ chlorhexidine gluconate mouthwash in children. J Int Soc Prev Commun Dentistry. 2015;5:218-26.

7. Oboh G, Rocha J. Polyphenols in red pepper [(Capsicum annuum var. aviculare) (Tepin)]. Eur Food Res Technol. 2007:225(2):239-47.

8. Halliwell B, Gutteridge J. Free radicals in biology and medicine: Oxford University Press; 2007.

9. Krishnaiah D, Sarbatly R, Nithyanadam R. A review of the antioxidant potential of medicinal plant species. Food Bioprod Process. 2011;89(3):21733

10. Burkill HM. The Useful Plants of West Tropical Africal 2nd Ed. (Vol. 1): Royal Garderns Kew; 1985.

11. Dickson R, Annan K, Komlaga G. Pharmacognostic standardization of the leaves and root bark of Caesalpinia benthamiana. Pharm J. 2011;3(24):31-4.

12. NCCLS. (1999). Methods for determining bactericidal activity of antimicrobial agents: approved guideline.

13. Kang C, Hah D, Kim C, Kim Y, Kim E, Kim J. Evaluation of antimicrobial activity of the methanol extracts from 8 traditional medicinal plants. Toxicol Res. 2011;27(1):31-6.

14. Perez $C$, Paul M, Bazerque P. An antibiotic assay by the agar well diffusion method. Acta Biol Med Exp. 1990;15:113-5. 
15. Pottumarthy $S$, Fritsche $T$, Jones R. Activity of gemifloxacid tested against Neisseria gonorrhoeae isolates including antimicrobial-resistant phenotypes. Diagn Microbiol Infect Dis. 2006;54:127-34

16. Osamudiamen PM, Oluremi BB, Oderinlo OO, Aiyelaagbe OO. Transresveratrol, piceatannol and gallic acid: potent polyphenols isolated from Mezoneuron benthamianum effective as anticaries, antioxidant and cytotoxic agents. Sci Afr. 2020;7:1-7.

17. Dickson R, Houghton P, Hylands P. Antimicroblal, resistance-modifying effects, antioxidant and free-radical scanvenging activities of Mezoneuron benthamianm Biall., Securinega virosa Roxb. \& wild, and Microglossa pyrifolla lam. S. Phytother Res. 2006;20:41-5.

18. Fayemi SO, Osho A, Atolani O. In vitro anticandidal and antioxidant potential of Mezoneuron benthamianum. J Acute Dis. 2012;1(2):120-5.

\section{Publisher's Note}

Springer Nature remains neutral with regard to jurisdictional claims in published maps and institutional affiliations.

\section{Submit your manuscript to a SpringerOpen ${ }^{\circ}$ journal and benefit from:}

- Convenient online submission

- Rigorous peer review

- Open access: articles freely available online

High visibility within the field

- Retaining the copyright to your article

Submit your next manuscript at $\boldsymbol{\nabla}$ springeropen.com 